\title{
Regulation of neuropeptide $Y$ mRNA expression in cultured human pheochromocytoma cells
}

\author{
Jianqi Liu ${ }^{1,2}$, Arvi I Kahri ${ }^{1}$, Päivi Heikkilä ${ }^{1}$ and Raimo Voutilainen ${ }^{1,2}$ \\ ${ }^{1}$ Department of Pathology, PO Box 21, University of Helsinki, FIN-00014 Helsinki, Finland and ${ }^{2}$ Department of Pediatrics, \\ Kuopio University Hospital, FIN-70210 Kuopio, Finland
}

(Correspondence should be addressed to J Liu; Email: Jiangi.Liu@helsinki.fi)

\begin{abstract}
The expression of the neuropeptide Y (NPY) gene varies considerably in human pheochromocytomas, but the mechanisms for this variation have not been clarified. To investigate the regulation pattern of the NPY gene in human pheochromocytomas, we screened 16 pheochromocytomas and 9 normal adrenal tissues with Northern blots. The expression level of NPY mRNA in normal adrenal medulla was low and relatively constant, while the pheochromocytomas showed a very wide variation in NPY mRNA levels in both malignant and benign tumors. This indicates that NPY gene expression is not correlated with malignancy in pheochromocytomas. In primary cultures of human pheochromocytoma cells, nerve growth factor treatment (causing neuronal differentiation) increased NPY mRNA accumulation 2- to 5 -fold $(P<0.05)$. NPY mRNA levels were also induced by protein kinase modulators $(\mathrm{Bu})_{2}$ cAMP and staurosporine in the cultures $(P<0.05)$. In contrast, treatment with dexamethasone and IGF-II (causing or linked with chromaffin differentiation) reduced NPY mRNA accumulation $(P<0.05)$. These data show that the regulation pattern of NPY mRNA expression in cultured human pheochromocytoma cells is different from that previously described in rat pheochromocytoma PC12 cells. Regulation of NPY mRNA expression in primary cultures by these differentiating factors suggests that the expression of NPY mRNA in pheochromocytoma tissues may be associated with the neuronal differentiation of the tumor cells affected by multiple factors.
\end{abstract}

European Journal of Endocrinology 141 431-435

\section{Introduction}

Neuropeptide Y (NPY) is a 36 amino acid peptide widely expressed by neurons in the central and peripheral nervous systems as well as by adrenal medullary cells (1). It is secreted from adrenal chromaffin cells on nerve stimulation (2). As a neuroendocrine hormone in adrenals, NPY can inhibit catecholamine release from chromaffin cells (3), and modulate the sensitivity of zona glomerulosa cells to adrenocorticotropin stimulation (4).

High concentrations of circulating NPY immunoreactivity have been reported in patients with pheochromocytomas $(5,6)$, especially in those with malignant forms (7). Both NPY peptide and mRNA levels in these tumors vary considerably. However, no statistically significant correlation between plasma NPY immunoreactivity and tumor mass or tumor content of the peptide was found $(6,8)$. In fact, malignant tumors tended to have lower NPY gene expression than benign ones (9). Because most pheochromocytomas with strong NPY immunoreactivity are well-differentiated tumors, it was suggested that induction of NPY gene expression in pheochromocytoma cells might depend on their differentiation status (10).
The mechanisms of NPY gene regulation in human pheochromocytomas are not yet well understood due to the very few human studies. The well-established rat pheochromocytoma PC12 cell line increased in NPY mRNA and cellular peptide levels during nerve growth factor (NGF)- or dexamethasone-induced differentiation, but no change in NPY concentration in the conditioned media was detected $(11,12)$. Cultured human pheochromocytoma cells had a higher NPY content than freshly dissociated cells from the same tumors (13). Since the in vitro condition also promoted neuron-like differentiation, it appeared that the environment favoring expression of the neuronal phenotype also favored NPY production in human pheochromocytoma cells. However, differences may exist between human and rat PC12 pheochromocytoma cells in the regulation of NPY expression. For example, NPY peptide was not detected in the conditioned medium of human pheochromocytoma cells, long-term treatment with NGF did not increase NPY in human cells, and induction of the chromaffin phenotype by dexamethasone decreased NPY content in human pheochromocytoma cells (13). To shed more light on the regulation of NPY expression in human pheochromocytomas, we 


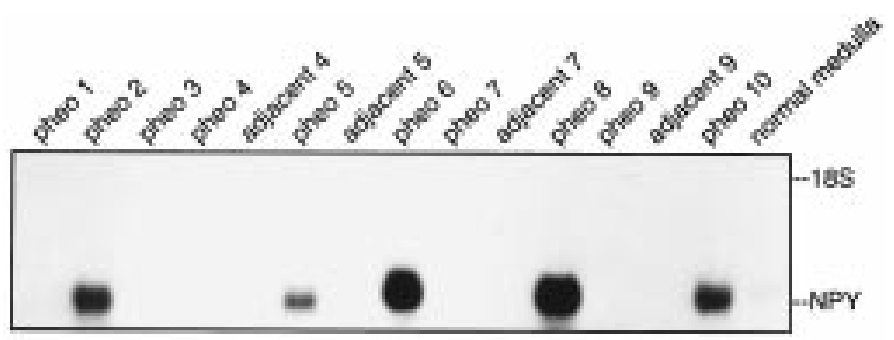

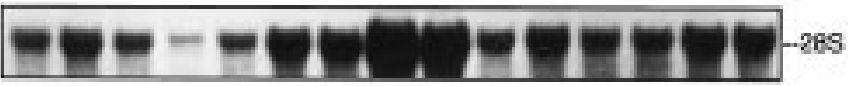

Figure 1 Expression of NPY mRNA in pheochromocytomas (pheo), the tumor-adjacent adrenal glands and a normal adrenal medulla in vivo. Total RNA was extracted from frozen tumor or normal tissues. Pheochromocytomas 1-3 were malignant, and the others were benign. The Northern blot was prepared with $20 \mu \mathrm{g}$ RNA for each lane, and the RNA was transferred onto a nylon membrane. The filter was sequentially hybridized with a ${ }^{32} \mathrm{P}$-labeled NPY oligonucleotide probe and a $28 \mathrm{~S}$ ribosomal RNA cDNA probe. The migration of $18 \mathrm{~S}$ ribosomal RNAs is indicated. measured NPY mRNA expression in these tumors by Northern blot hybridization, and examined the effects of several differentiating agents on NPY gene expression in primary cultures of human pheochromocytoma cells.

\section{Materials and methods}

\section{Tissues and cell cultures}

Normal adrenal glands were obtained from nine patients who were undergoing nephrectomy for kidney tumors. Pheochromocytomas and adrenal tissues adjacent to these tumors were obtained from 16 patients during operations performed at the Department of Surgery, Helsinki University Central Hospital. Diagnosis was established based on both clinical data and histopathological analysis. Four of the pheochromocytomas were malignant and 12 were benign. Tumoradjacent adrenal tissue was collected from five patients. The tissue samples were processed as described previously (14). This research protocol was approved by the Local Ethical Committee. Briefly, normal adrenal cortical and medullary tissues were carefully dissected from five adrenals. Part of the pheochromocytoma and normal adrenal tissues were frozen in liquid nitrogen and then stored at $-70^{\circ} \mathrm{C}$ before extraction of total RNA. The remaining tissues were processed for primary cultures. After digestion with collagenase-dispase and deoxyribonuclease-I, the dispersed cells were maintained in Dulbecco's Modified Eagle's Medium-Ham's F-12 medium containing $10 \%$ fetal calf serum for 5-7 days before the test agents were added (14). Phase contrast light microscopy was employed to examine the growth and morphological characteristics of the cultured cells. All experiments were performed in triplicate and repeated at least twice with tissues from different patients. 7S-NGF, dexamethasone, 12-O-tetradecanoyl phorbol-13-acetate (TPA), and dibutyryl cyclic AMP $\left((\mathrm{Bu})_{2} \mathrm{cAMP}\right)$ were purchased from Sigma Chemical Co. (St Louis, MO, USA). Insulin-like growth factor-II (IGF-II) was from Bachem (Bubendorf, Switzerland). Staurosporine was obtained from Boehringer Mannheim (Mannheim, Germany).

\section{RNA analysis}

Isolation of total and cytoplasmic RNA, Northern blotting and hybridizations were carried out as described previously (14). A 30-mer oligonucleotide probe for NPY mRNA was synthesized at the Institute of Biotechnology, University of Helsinki. The sequence was 5'- TCA TCA AGA GGT CTG AAA TCA GTG TCT CTG -3', corresponding to nucleotides 295-324 of the human NPY cDNA (15). The mouse $28 \mathrm{~S}$ ribosomal RNA cDNA probe (16) was used as a loading control. All mRNA data shown were normalized with respect to $28 \mathrm{~S}$ RNA values. Differences in the RNA levels between various types of adrenal tissues in vivo or different treatments in vitro were assessed by the Mann-Whitney test. The level of significance was chosen as $P<0.05$.

\section{Results}

We screened 16 pheochromocytomas and 9 normal adrenal tissues for NPY mRNA expression. Northern blots hybridized with the NPY oligonucleotide probe

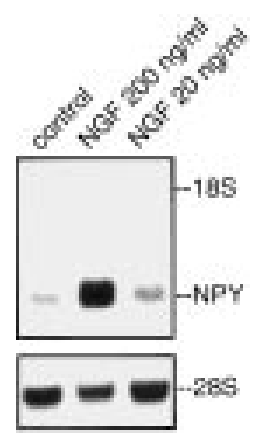

Figure 2 Induction of NPY mRNA expression by NGF in a primary culture of pheochromocytoma cells. The cells were first cultured without stimulation for 6 days, and then treated with NGF at concentrations indicated for 3 days. The Northern blot was prepared with $10 \mu \mathrm{g}$ cytoplasmic RNA in each lane. The filter was hybridized as described in Fig. 1. The experiment was repeated four times and the results were similar. 


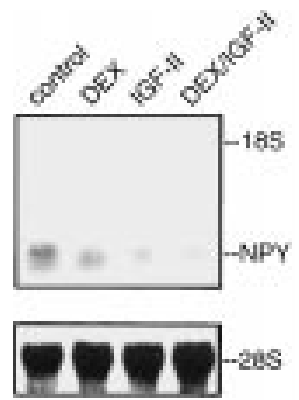

Figure 3 Northern blot of cytoplasmic RNA from cultured pheochromocytoma cells treated with dexamethasone (DEX; $1 \mu \mathrm{mol} / \mathrm{I})$ and IGF-II $(100 \mathrm{ng} / \mathrm{ml})$. The cells were first cultured for 7 days, and then treated with the agents for 3 days. Each lane contained $10 \mu \mathrm{g}$ RNA and the filter was hybridized as described in Fig. 1. The experiment was repeated twice with cells from different patients and the results were similar.

showed the NPY transcript of about 800 nucleotides in size in some pheochromocytoma and normal adrenal medullary tissues, but not in normal adrenal cortex or the tumor-adjacent adrenal glands. After long enough exposure of the Northern blots, low and relatively constant expression of NPY mRNA was detected in all normal adrenal medullary samples. Although NPY mRNA was not detected in all pheochromocytomas, very strong expression of NPY mRNA was detected in some samples including both malignant and benign pheochromocytomas (Fig. 1).

In primary cultures derived from all pheochromocytomas, expression of NPY mRNA was detectable in the absence of any stimulation up to at least 2 weeks. During neuronal differentiation induced by NGF at $200 \mathrm{ng} / \mathrm{ml}$ for 3 days, expression of NPY mRNA was increased 2 - to 5 -fold $(P<0.05, n=4$ from different patients), and this effect was still detectable with NGF at
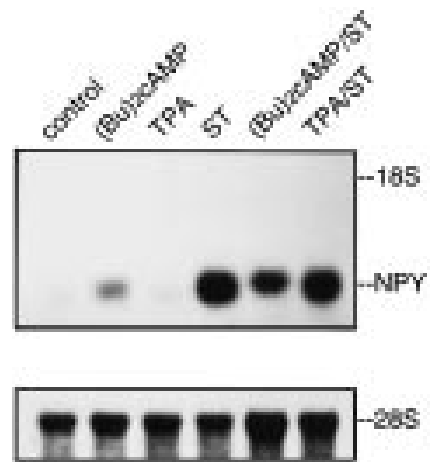

Figure 4 The effects of $(\mathrm{Bu})_{2} \mathrm{CAMP}(1 \mathrm{mmol} / \mathrm{l})$, TPA $(160 \mathrm{nmol} / \mathrm{l})$ and staurosporine (ST; $100 \mathrm{nmol} / \mathrm{l})$ on NPY mRNA expression in vitro. Pheochromocytoma cells were cultured for 5 days before the indicated treatment for 3 days. The Northern blot was prepared with $10 \mu \mathrm{g}$ cytoplasmic RNA in each lane. The filter was hybridized as described in Fig. 1. The experiment was repeated three times with cells from different patients, and the results were comparable.
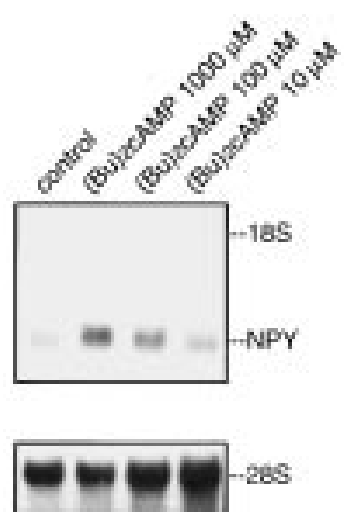

Figure 5 Northern blot of cytoplasmic RNA from cultured pheochromocytoma cells treated with $(\mathrm{Bu})_{2} \mathrm{CAMP}$ at the concentrations indicated. The cells were first cultured for 5 days, and then stimulated for 3 days. Each lane contained $15 \mu \mathrm{g}$ RNA and the filter was hybridized as described in Fig. 1. The experiment was repeated twice with cells from different patients and the results were similar.

$20 \mathrm{ng} / \mathrm{ml}$ (Fig. 2). However, $24 \mathrm{~h}$ treatment was not long enough to induce NPY mRNA expression. In contrast, treatment with dexamethasone $(1 \mu \mathrm{mol} / \mathrm{l})$ for 1 and 3 days reduced NPY mRNA accumulation approximately 30 and $50 \%$ respectively $(P<0.05)$ (Fig. 3). Since dexamethasone is able to increase IGF-II gene expression in pheochromocytoma cells (14), we used IGF-II to treat the cells. IGF-II $(100 \mathrm{ng} / \mathrm{ml})$ reduced NPY mRNA accumulation more than $50 \%$ after 3 days of incubation $(P<0.05, n=3)$ (Fig. 3). To study the role of different classes of protein kinases in the regulation of NPY mRNA expression, we treated cultured pheochromocytoma cells with different protein kinase modulators. The NPY mRNA levels were increased by $(\mathrm{Bu})_{2} \mathrm{cAMP}(1 \mathrm{mmol} / \mathrm{l}$; activates protein kinase A) and staurosporine $(100 \mathrm{nmol} / \mathrm{l}$; a general protein kinase inhibitor) after 3 days of treatment
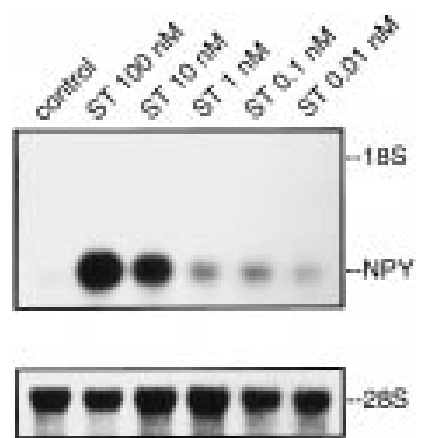

Figure 6 Northern blot of cytoplasmic RNA from cultured pheochromocytoma cells treated with staurosporine (ST) at the concentrations indicated. The cells were first cultured for 5 days, and then treated with staurosporine for 3 days. Each lane contained $15 \mu \mathrm{g}$ RNA and the filter was hybridized as described in Fig. 1. The experiment was repeated twice with cells from different patients and the results were comparable. 
( $P<0.05$ for both), but the response of NPY mRNA to TPA $(160 \mathrm{nmol} / \mathrm{l}$; activates protein kinase $C$ in shortterm incubation, but depletes protein kinase $\mathrm{C}$ in longterm experiments) was not significant. Interestingly, the remarkable stimulatory effect of staurosporine on NPY mRNA accumulation was somehow inhibited by the combined treatment with $(\mathrm{Bu})_{2} \mathrm{cAMP}$, while TPA had no effect on the staurosporine-induced expression of NPY mRNA (Fig. 4). The stimulatory effects of both $(\mathrm{Bu})_{2} \mathrm{cAMP}$ and staurosporine were dose-dependent, with detectable effects from concentrations of $100 \mu \mathrm{mol} / \mathrm{l}$ and $0.01 \mathrm{nmol} / \mathrm{l}$ upwards respectively (Figs 5 and 6). The stimulatory effect of $(\mathrm{Bu})_{2} \mathrm{cAMP}$ on NPY mRNA accumulation was detected by $24 \mathrm{~h}$ of treatment, whereas staurosporine did not have a significant effect at this time point (data not shown).

\section{Discussion}

In this study, we confirmed the previous reports that both malignant and benign pheochromocytomas express NPY mRNA (9). This indicates that the level of NPY expression does not correlate with malignancy, and thus it is not a reliable marker for distinguishing malignant pheochromocytomas from benign ones. The wide variation of NPY mRNA levels may reflect heterogeneity in the differentiation status of pheochromocytomas.

NGF is able to induce differentiation of human pheochromocytoma cells to sympathetic neuron-like cells $(13,17)$. Therefore, we used NGF to treat cultured pheochromocytoma cells. NGF increased NPY mRNA expression in primary cultures of pheochromocytoma cells. This seems to be in contrast to a previous report where NGF did not increase the cellular content of NPY after long-term incubation (13). However, in that study, the long-term (21 days) culture without any additives induced spontaneous neuronal differentiation with process outgrowth and high levels of immunoreactive NPY. NGF may not be able to further increase NPY gene expression in these conditions (13). Therefore, we used a relatively short-term (5-10 days) culture system to clarify if NGF could accelerate chromaffin cell differentiation and NPY mRNA accumulation. Our results confirmed that NGF indeed increased the expression of NPY mRNA in cultured human pheochromocytoma cells. In contrast, we found that dexamethasone slightly reduced the expression of NPY mRNA. This is in agreement with a previous report that dexamethasone-treated cells contained less NPY than cultures with no additives (13). Since dexamethasone is able to increase IGF-II gene expression in pheochromocytoma cells (14), and IGF-II expression is a marker for extraadrenal chromaffin cell differentiation in neuroblastomas (18), we treated pheochromocytoma cells with IGF-II. NPY mRNA levels decreased during IGF-II treatment. We do not know if the dexamethasone-induced decrease of NPY mRNA is mediated by increased IGF-II expression in cultured pheochromocytoma cells (14).
The effects of NGF are initiated through second messenger cascades, including protein kinase $\mathrm{A}$ and $\mathrm{C}$ pathways. In PC12 cells, NPY gene expression is stimulated by forskolin and TPA (19). Our results indicated that the protein kinase $\mathrm{A}$, but not protein kinase $\mathrm{C}$, pathway is involved in the modulation of NPY gene expression in human pheochromocytoma cells, further demonstrating the difference between the rat PC12 cells and human pheochromocytoma cells. The general protein kinase inhibitor staurosporine can induce a mature neuronal phenotype in human neuroblastoma and rat PC12 cells through a protein kinase $\mathrm{C}$-independent pathway in the absence of both the trk and p75 NGF receptors, suggesting staurosporine as a unique neurotropic compound (20, 21). NPY mRNA was increased during staurosporineinduced differentiation of SH-SY5Y human neuroblastoma cells along the sympathetic neuronal lineage (20). Similarly, staurosporine increased NPY mRNA accumulation in our pheochromocytoma cultures. Although both $(\mathrm{Bu})_{2} \mathrm{cAMP}$ and staurosporine increased the steady state levels of NPY mRNA, combined treatment with these two agents resulted in less stimulation than staurosporine alone, indicating that there was an interaction between the signaling pathways used by these two agents. Furthermore, the mechanisms underlying the regulation of NPY gene expression could be cell and species specific. For example, TPA increased the expression of NPY mRNA in PC12 cells and in a neuroblastoma cell line LA-N-5 via different mechanisms (19), whereas our results showed no change in NPY mRNA level after TPA treatment.

Taken together, our data reveal that the expression of NPY gene in cultured human pheochromocytoma cells is regulated by multiple differentiating factors and suggest that the expression of NPY mRNA in pheochromocytoma tissues may be associated with the neuron-like differentiation induced by different local factors.

\section{Acknowledgements}

Ms Merja Haukka and Ms Eija Heiliö are thanked for their technical assistance. Dr Johanna Arola is thanked for her help in the preparation of the tissues. This work was financially supported by the Cancer Society of Finland, the Culture Foundation of Finland, the Jalmari and Rauha Ahokas Foundation (to JL), and Kuopio University Hospital Research Contract No. 5107 (to $\mathrm{RV})$.

\section{References}

1 White JD. Neuropeptide Y: a central regulator of energy homeostasis. Regulatory Peptides 199349 93-107.

2 Allen JM, Biecham PMM, Bloom SR \& Edwards AV. Release of neuropeptide $\mathrm{Y}$ in response to splanchnic nerve stimulation in the conscious calf. Journal of Physiology 1984357 401-408. 
3 McCullough LA \& Westfall TC. Mechanism of catecholamine synthesis inhibition by neuropeptide $\mathrm{Y}$ : role of $\mathrm{Ca}^{2+}$ channels and protein kinases. Journal of Neurochemistry 199667 1090-1099.

4 Hinson JP, Cameron LA \& Kapas S. Neuropeptide Y modulates the sensitivity of the rat adrenal cortex to stimulation by ACTH. Journal of Endocrinology 1995145 283-289.

5 Pruszczyk P, Wocial B, Ignatowska-Switalska H, Feltynowski T, Ellafi M, Januszewicz A, Lapinski M, Zukowska-Grojec Z \& Januszewicz W. Does plasma neuropeptide-Y immunoreactivity in patients with pheochromocytoma depend on hormonal activity of the tumor? Clinica Chimica Acta 1995243 205-212.

6 deS Senanayake P, Denker J, Bravo EL \& Graham RM. Production, characterization, and expression of neuropeptide $\mathrm{Y}$ by human pheochromocytoma. Journal of Clinical Investigation 199596 2503-2509.

7 Grouzmann E, Comoy E \& Bohuon C. Plasma neuropeptide-Y concentrations in patients with neuroendocrine tumors. Journal of Clinical Endocrinology and Metabolism 198968 808-813.

8 Januszewicz W, Wocial B, Ignatowska-Switalska H, DutkiewiczRaczkowska M, Feltynowski T, Januszewicz A, Lapinski M, Zukowska-Grojec Z \& Szostek M. Alterations in plasma neuropeptide $\mathrm{Y}$ immunoreactivity and catecholamine levels during surgica removal of pheochromocytoma. Journal of Hypertension 199816 543-547.

9 Helman LJ, Cohen PS, Averbuch SD, Cooper MJ, Keiser HR \& Israel MA. Neuropeptide Y expression distinguishes malignant from benign pheochromocytoma. Journal of Clinical Oncology 19897 1720-1725.

10 Osamura RY, Tsutsumi Y, Yanaihara N, Imura H \& Watanabe K. Immunohistochemical studies for multiple peptide-immunoreactivities and co-localization of Met-enkephalin-Arg-Gly-Leu neuropeptide $\mathrm{Y}$ and somatostatin in human adrenal medulla and pheochromocytomas. Peptides 19878 77-87.

11 Higuchi H, Iwasa A \& Yokokawa K. High levels of expression of neuropeptide Y mRNA in human phaeochromocytomas. Clinical and Experimental Pharmacology and Physiology 199421 359365.

12 Rajakumar PA, Westfall TC \& Devaskar SU. Neuropeptide Y gene expression in immortalized rat hippocampal and pheochromocytoma-12 cell lines. Regulatory Peptides 199873 123-131.

13 Tischler AS, Allen JM, Costopoulos D \& Bloom SR. Increased content of neuropeptide $\mathrm{Y}$ in human pheochromocytoma cell cultures. Journal of Clinical Endocrinology and Metabolism 198561 303-305.

14 Liu J, Kahri AI, Heikkilä P, Blum WF \& Voutilainen R. Glucocorticoids increase insulin-like growth factor-II mRNA accumulation in cultured human phaeochromocytoma cells. Journal of Endocrinology 1994142 29-35.

15 Minth CD, Bloom SR, Polak JM \& Dixon JE. Cloning, characterization, and DNA sequence of a human cDNA encoding neuropeptide tyrosine. Proceedings of the National Academy of Sciences of the USA $1984814577-4581$.

16 Arnheim N. Characterization of mouse ribosomal gene fragments purified by molecular cloning. Gene $1979783-96$.

17 Pfragner R \& Walser V. Long-term tissue culture of human pheochromocytomas. Experimentelle Pathologie 198018 423429.

18 Hedborg F, Ohlsson R, Sandstedt B, Grimelius L, Hoehner JC \& Påhlman S. IGF2 expression is a marker for paraganglionic/SIF cell differentiation in neuroblastoma. American Journal of Pathology $1995146833-847$.

19 Lerchen RA, Yum DY, Krajcik R \& Minth-Worby CA. Transcriptional vs posttranscriptional control of neuropeptide $\mathrm{Y}$ gene expression. Endocrinology 1995136 833-841.

20 Jalava A, Akerman K \& Heikkilä J. Protein kinase inhibitor, staurosporine, induces a mature neuronal phenotype in SH-SY5Y human neuroblastoma cells through an alpha-, beta-, and zetaprotein kinase C-independent pathway. Journal of Cellular Physiology 1993155 301-312.

21 Rasouly D, Shavit D, Zuniga R, Elejalde RB, Unsworth BR, Yajon A, Lazarovici P \& Lelkes PI. Staurosporine induces neurite outgrowth in neuronal hybrids (PC12EN) lacking NGF receptors. Journal of Cellular Biochemistry 199662 356-371.

Received 17 February 1999

Accepted 28 June 1999 